\title{
"I am 30 and I have nothing": the context of reception and the lived experiences of foreign migrants working as car guards in Johannesburg's West Rand
}

\author{
Phillip Frederick Blaauw (1) Marinda Pretorius ${ }^{(\mathbb{D}}$
}

Accepted: 24 January 2022 / Published online: 12 February 2022

(C) The Author(s), under exclusive licence to Springer Nature B.V. 2022

\begin{abstract}
South Africa is an important destination for immigrants from sub-Saharan Africa. Migration and its impact remain significant in South African society: demographically, politically, economically and socially. Many migrants are forced to take up informal income-generating activities such as day labouring and car guarding. This study investigated the lived experiences and context of reception of foreign migrant car guards using a survey instrument among formal car guards working in the parking lots of shopping centres in the western part of Johannesburg. Demographic data, employment history and objective and subjective indicators were used to assess their socio-economic and labour market outcomes. The subjective well-being of the migrant car guards was analysed using descriptive statistics and an ordered probit model. The study revealed the extent and depth of the vulnerabilities experienced by individuals subjected to working in the informal economy as well as being migrants. They have to tolerate sub-standard employment in the informal sector as there are no other viable options. At the same time, they must provide for dependants back home.
\end{abstract}

P. F. Blaauw

School of Economic Sciences, North-West University,

Potchefstroom Campus, Potchefstroom, South Africa

M. Pretorius $(\square)$

School of Economics, University of Johannesburg, Auckland Park Campus, Johannesburg, South Africa e-mail: marindap@uj.ac.za
The result is emotional stress and low levels of subjective well-being. Migrant car guards' unique labour market status and relationship with the shopping centres and car guard companies deserve urgent research attention.

Keywords Car guarding - African migrants · Subjective well-being (SWB) $\cdot$ Johannesburg $\cdot$ South Africa

\section{Introduction}

South Africa continues to be a crucial African destination for immigrants from across sub-Saharan Africa. Issues around migration remain significant in South African society, not merely demographically but also politically, economically and socially. According to the official 2011 census (Statistics South Africa, 2018), 2.2 million immigrants lived in South Africa at the time $-4.2 \%$ of the total population. The latest estimate from the International Organisation for Migration puts the 2019 figure at 4.2 million migrants (7.2\% of the population) in South Africa (IOM, 2019). The figures are hotly debated and several official organs of the South African government claim that these figures are grossly overstated.

There is no question, however, that South Africa remains an attractive destination for immigrants, primarily from southern Africa and the rest of the African continent, and that there has been a significant 
influx of migrants and asylum seekers over the past few years (Crea et al., 2017; Nkomo, 2019). Statistics South Africa (2018) estimates that South Africa will be the recipient of net immigration of 1.02 million people between 2016 and 2021. Nearly half (47.5\%) of international migrants live in Gauteng, the province that is considered the economic hub of South Africa. Many of these international migrants are without official documents (Statistics South Africa, 2018).

In Gauteng, international migrants must compete with the established residents and growing numbers of internal migrants who also hope to escape South Africa's high unemployment in the province (Charman \& Petersen, 2015; Theodore et al., 2017). Migrants often have very few opportunities in terms of stable employment. Consequently, many of them have little option but to turn to the informal economy, such as day labour or car guarding, for their livelihood (Crush et al., 2015a). Furthermore, it is usually assumed that undocumented immigrants experience worse socio-economic consequences than locally born workers (Bernhardt et al., 2013; Doussard, 2013; Theodore et al., 2017; Woolfson et al., 2014).

Conditions in Johannesburg are no different: the environment can be a hostile place in which to conduct a small business as a result of the antagonistic attitude of the local government and other workers, as well as various other factors (e.g. hostile local policy actors, issues of xenophobia among residents, and lacking institutional infrastructure for successful immigrant incorporation) in the context of migration (Theodore et al., 2018; Visser, 2017; Winders, 2014). Furthermore, Myroniuk and Vearey (2014) note that issues of migrant integration and the context of reception foreign migrants face may indeed be more sector specific than what was originally accepted. The context of reception within the field of migration study refers to the process of how the institutional, labour market, and social structures of a specific migrant-receiving environment shape new arrivals' settlement experiences and opportunities for mobility (Asad, 2015; Portes \& Bach, 1985; Portes \& Rumbaut, 2006). The context of reception is influenced by more than government policy and regulation. The state of local economies, geographic location, history, and culture, are all factors responsible for shaping the context of reception for new migrants (Martinez et al., 2011).
In acknowledgement of this situation and in response to the dearth of literature on the incorporation of foreign migrants in informal employment activities in the global South (Theodore et al., 2017), we sought to contribute to the literature by investigating the context of reception, lived experiences and socio-economic outcomes of foreign migrants working as car guards in Johannesburg's West Rand.

We identified several reasons to focus on car guarding in our research. Firstly, foreign migrants in Gauteng are often confronted with few alternatives to earn a living other than different forms of informal employment or self-employment (Theodore et al., 2017). These informal economic activities, for example day labouring, are often characterised by a disregard of labour standards with very few options to move into higher-wage jobs and more stable employment in the formal sector (Theodore et al., 2017). Secondly, car guarding is another such informal economic activity unique to the South African urban landscape-where the possibility for the exploitation of workers is a constant reality (Foster \& Chasomeris, 2017; Steyn et al., 2015). Yet, no previous research has investigated the subjective well-being (SWB) of foreign migrants earning a living as car guards-a gap our study had as its research agenda.

The article is set out as follows: the following section briefly discusses car guarding as a manifestation of economic informality. The relevant literature on issues about migration and the integration of migrants in South Africa's local economies is discussed. Next, the methodology is described, followed by various objective and subjective indicators of the lived experiences of car guards. We conclude with suggested recommendations for policy and further research.

\section{The car guard industry in South Africa: evolvement and a review of the literature}

The car guard industry in South Africa developed due to high and rising levels of unemployment (32.6\% in terms of the narrow definition in the first quarter of 2021) and increasing levels of crime (including vehicle theft) in the country. In 2018, for example, there were 25705 cases of motor vehicle theft in Gauteng (SAPS, 2018). According to the latest publically available statistics, there were an estimated 88 000 incidences of motor vehicle theft in the reporting 
period of 2019/20, affecting 0.5\% of South African households (Statistics South Africa, 2020). This represents a $7.6 \%$ decrease compared to the previous year. Gauteng (45 000) again recorded the highest number of households that experienced car theft (Statistics South Africa, 2020).

In the early 1990 s unemployed men started to show motorists where open parking spaces were and offered to guard vehicles in exchange for money (McEwen \& Leiman, 2008, p. 4). From its origin in Durban's beachfront, similar initiatives spread throughout South Africa (Kitching, 1999; Blaauw \& Bothma, 2003, p. 41; Steyn, 2018). As an industry, car guarding developed and grew spontaneously at both local and national levels, without assistance or involvement from any level of government (McEwen \& Leiman, 2008).

Some people view car guards as street-corner entrepreneurs as they are paid to watch people's vehicles. Other commentators believe that car guards are merely an irritation, offer no real value and are a glorified form of begging (Foster \& Chasomeris, 2017). The media also report variously on stories of courage among car guards but also of their involvement in crime, such as the selling of drugs and even rape (Chambers, 2018; Corruptionwatch, 2016).

Whether viewed positively or negatively, many unemployed people work as car guards across South Africa-including migrants and refugees who face several barriers to enter the formal sector (Foster et al., 2021; McEwen \& Leiman, 2008). The principle is the same. They offer to guard motorists' vehicles in exchange for a gratuity ('tip') from them upon their return. The value of this gratuity lies exclusively at the discretion of the motorist (Saunders \& Lynn, 2010). Car guards are active in various public spaces where drivers park their vehicles (e.g., central business districts, commercial parks and shopping centres) (Foster \& Chasomeris, 2017; Steyn, 2018).

The literature distinguishes between so-called formal and informal car guards. Formal car guards' activities are coordinated by a supposed car guard agency on behalf of the management or owners of shopping centres (Steyn, 2018). These agencies act as pseudo labour brokers. Reports in the media and academic literature suggest that the car guards in this dispensation pay a fixed daily tariff to the agency or directly to the shopping centre for them to provide their services in the parking area (Blaauw \& Bothma,
2003; Kitching, 1999; Steyn, 2018; Steyn et al., 2015). The car guards find themselves in an unenviable position to enjoy little or even no protection under the existing formal labour legislation (Foster \& Chasomeris, 2017; Foster et al., 2021).

On the other hand, informal car guards have no such relationship with any agency or shopping centre. They work entirely individually and often in the central business areas of towns and cities. Their income tends to be even lower than that of the formal car guards (Blaauw \& Bothma, 2003, p. 41). The study on which this article is based focused on the former group.

In addition to the daily fee to be paid to an agency, formal car guards share the same vulnerabilities as other informal economy participants-most notably the uncertain level of earnings (Bernstein, 2003; Foster \& Chasomeris, 2017; Foster et al., 2021). Earnings are a function of the willingness of the driver to pay for the service. In turn, this depends on the driver's attitude towards the car guard (Foster \& Chasomeris, 2017; Steyn, 2018).

This aspect was a topic of two studies from a psychological and economic point of view as reported in the literature. Saunders and Petzer (2009) found that approximately $69 \%$ of drivers in their study gave a gratuity to the car guards due to internalised feelings on the industry. Examples include the need to reward someone for providing a good service or establishing social status and feelings of acceptance (Saunders \& Lynn, 2010, p. 112). Furthermore, Saunders and Lynn (2010) argue that from a pure mainstream economic thinking point of view, it is not economically rational to give a car guard a donation as it is an avoidable expense. Foster and Chasomeris (2017) highlight the possible positive externality for the driver not tipping-even if no tip is given, the mere presence of a car guard may act as deterrence for motor vehiclerelated crime. Steyn et al., (2015, p. 16) and Steyn (2018) share this view. For the most part, however, formal studies on car guards and their activities in South Africa are relatively scarce (Blaauw \& Bothma, 2003; Steyn, 2018).

A few studies looked at the socio-economic aspects of the car guarding phenomenon using various case studies. Kitching (1999) conducted exploratory research in this regard in Bloemfontein in the Free State province. Blaauw and Bothma (2003) built on the Kitching (1999) study and investigated 
car guarding as an example of South Africa's informal sector activities. In the study, 149 car guards in Bloemfontein were interviewed. Blaauw and Bothma (2003) compared the income of car guards with that of waiters and domestic workers in the same city and found that the income earned by the car guards was significantly lower than the other two jobs. Both studies concluded that the car guard industry functions as a survival mechanism with little possibility of its participants migrating to formal sector employment (Blaauw \& Bothma, 2003; Kitching, 1999).

In a later study in Pretoria, Steyn et al. (2015) also found that many of the 144 car guards in their sample struggled to survive financially, specifically due to the daily tariff they have to pay to the car guard agency or shopping centre. This amount is payable irrespective of the amount they earned for the day in the form of tips (Steyn et al., 2015). Foster and Chasomeris (2017) found that the average car guard in their Durban sample worked six days a week, up to nine hours per day-almost all of this time spent standing and walking in between the vehicles in their allotted area. Their study confirmed that working as a car guard is a high-risk endeavour in terms of health (being exposed to the harsh South African climate for up to nine hours a day) and the very real possibility of verbal or even physical abuse (Foster \& Chasomeris, 2017). In a follow-up study in Durban, Foster et al. (2021) concluded that the real income earned by car guards in Durban decreased since the 2017 study of Foster and Chasomeris.

Potgieter et al. (2003) investigated the role of car guards in preventing motor vehicle-related crime in Empangeni in KwaZulu-Natal. They concluded that women especially experienced the role of car guards in safeguarding their vehicles in a positive light (Potgieter et al., 2003). Another study (McEwen \& Leiman, 2008) looked at the development and functioning of the industry. Using a qualitative approach, they concluded that the labour market of car guards took on the character of a quasi-public good (McEwen \& Leiman, 2008).

One of the two studies focusing on migrants was that of Bernstein (2003) in Cape Town, who conducted interviews with 53 car guards and 200 drivers about their opinions and experiences in Long Street and Kloof Street in the city centre. In his findings he referred specifically to the levels of xenophobia experienced by foreign migrants working as car guards.
He also found that the perception that car guards were pestering drivers was not as common as often reported in the media, but that car guards were regularly harassed by the police and private security firms (Bernstein, 2003). The second study was that of Steyn (2018) in Pretoria. He compared the experiences of foreign migrants with those of South African-born car guards and found differences between the migrant and local car guards in relation to education, household dynamics, relationships with motorists and their knowledge of South African labour legislation (Steyn, 2018).

The overall conclusion from the limited literature over the last 20 years is twofold. On the one hand, it reflects the social and economic vulnerabilities to which car guards are subjected. On the other hand, it illustrates the grey area in terms of labour market status and the power relations with the car guard agencies and shopping centres in which car guards often find themselves in. As with many other activities in the informal economy, car guards cannot plan for the future. Furthermore, any exogenous shock (such as the current COVID-19 pandemic) may have a catastrophic impact on the lives and livelihoods of car guards as they will not be able to earn any income. This may deplete any meagre savings they may have (in most cases meant for families in their home countries who are also in dire need of funds) and force them into the hands of unscrupulous money lenders who ask exuberant rates of interest for short-terms loans. These vulnerabilities formed the theme of our investigation into the lived experiences and integration of foreign-born migrants working as car guards in Johannesburg's West Rand.

Before the research methodology is explained, the relevant literature on the integration of foreign migrants is discussed as it pertains to the reality of migrants in general and migrants in informal forms of employment (such as car guards).

\section{Immigration and the informal economy}

Immigrants who are less skilled and especially those in the destination country illegally often find themselves in casualised sectors of the economy. Labour standards are repeatedly violated due to limited alternatives in the formal sector of the economy (Doussard, 2013; Theodore et al., 2017). 
The international literature provides convincing evidence of this pattern in the Global North (Theodore et al., 2009; Winders, 2014; Woolfson et al., 2014). In the European context, Solé et al. (1998) analysed the employment situation of non-European Union immigrants in Spain. The majority of immigrants (primarily Moroccan) found work as domestic workers (in the case of women), hotel and restaurant services, the building industry and the retail trade (Solé et al., 1998). All migrants experienced issues such as finding it difficult to obtain residence and labour permits (Solé et al., 1998). Across the world, the number of migrant workers in irregular or informal employment is increasing markedly, driven to some extent by the growing commercialisation of migration processes, including smuggling and trafficking - but also by the emergence or re-emergence of informal forms of employment in destination countries (ILO, 2004).

In South Africa, there is also ample evidence of active migrant involvement in the informal economy (Crush et al., 2015b; Thompson, 2016). Examples include the day labour market (Theodore et al., 2017, 2018), working as self-employed informal waste reclaimers (Viljoen et al., 2018), street trading and spaza shops (informal tuck shops) (Charman \& Peterson, 2015; Thompson, 2016), and car guarding (Foster \& Chasomeris, 2017; Foster et al., 2021; McEwen \& Leiman, 2008; Steyn, 2018). These workers may have no other option than to tolerate sub-standard employment since it may be the only viable opportunity available to them (Theodore et al., 2017).

Apart from working conditions, the literature on immigrants and informality in the South African context reveals the dominance of street traders as the unit of analysis and the issues of xenophobia on foreign migrants. The latter is no surprise because between 2002 and the middle of 2010, more than 400 Somali refugees, many of them informal traders, were murdered in South Africa (Tawodzera et al., 2015). Furthermore, the migrants often accuse the police of ignoring the xenophobic attacks on their businesses (Tawodzera et al., 2015). There is a rich literature in Southern Africa on the trends and practices of antimigrant expressions in the region, focusing on xenophobia and international migration (see Tevera 2013 for a collection of notable works including Charman and Piper 2012; Crush and Pendleton 2007; Danso and McDonald 2000; McKnight 2008; and Morapedi
2007). These studies were primarily located in the three major metropolitan centres (Johannesburg, Cape Town and Durban) because they had been at the centre of violent xenophobic events in the post-apartheid era (Tevera, 2013).

Several studies acknowledge the impact of community violence and the fear of xenophobia on migrants' ability to provide for their material needs (Crea et al., 2017). Apart from safety concerns, the correct documentation as a prerequisite for accessing meaningful employment forms another critical element in the literature. Nkomo (2019) confirms that documentation is the most pressing need for Congolese refugees and asylum seekers in Gauteng. Without documentation, they are struggling to access employment opportunities. This confirms what was found in an earlier study by Smit and Rugunanan (2014), namely that refugees and asylum seekers struggle to keep full-time employment because they do not have the required legal documents.

Exploitation issues naturally follow the pressing need for documentation at various levels (Crea et al., 2017). Corrupt officials often find immigrant workers easy targets for exploitation and bribes to obtain documentation (Crea et al., 2017; Smit \& Rugunanan, 2014). Exploitation is also encountered in other aspects of their daily lives, for example in the high rentals that foreign migrants often have to pay for accommodation (Nkomo, 2019; Smit \& Rugunanan, 2014). Some of the migrants considered in the studies indicated that they are forced to rent out some rooms or space to afford the rent for the whole apartment (Nkomo, 2019). More than one family lives in one room, leading to overcrowding and a lack of privacy (Nkomo, 2019; Smit \& Rugunanan, 2014). The combined effect of these issues culminates in migrants often finding it extremely difficult to make ends meet, leaving them vulnerable (Crea et al., 2017; Tevera, 2013).

The impact of these fears and daily struggles to survive manifests itself in heightened feelings of emotional distress and a low sense of emotional wellbeing among immigrants, as reported in the literature (Nkomo, 2019; Smit \& Rugunanan, 2014). However, the literature on the context of reception and integration on other informal employment activities in South Africa such as day labouring, waste picking and car guarding is not as rich. A few studies on immigrant involvement in day labouring (see Blaauw 
et al., 2012; Theodore et al., 2017, 2018) highlight the worsening plight of mainly Zimbabwean day labourers in South Africa, and Gauteng in particular. We found only one study (Steyn, 2018) that mentions migrants working as car guards in Pretoria. The context of reception and lived experiences of migrant car guards in Johannesburg was, therefore, the aim of our investigation in this study. The methodology is discussed in the next section.

\section{Methodology}

As mentioned previously, the West Rand was chosen as the geographical area for the study as it is an area where business and residential areas are constantly expanding. Several new shopping centres have been developed in this area in the last decade. The fieldwork for this study required a survey among the formal car guards working in the parking areas of the various shopping centres in the demarcated areas of the study. A quantitative research design was identified as the best option to obtain the required demographic data, employment history and objective and subjective indicators to assess the lived experiences of the migrant car guards in Johannesburg's West Rand. The research instrument was a questionnaire and the design was based on previous studies on car guards in South Africa (see e.g., Kitching, 1999; Blaauw \& Bothma, 2003; Potgieter et al., 2003; Steyn et al., 2015; Foster \& Chasomeris, 2017; Foster et al., 2021) and various studies on other informal economic activities (Theodore et al., 2017). The questionnaire consisted of a combination of around fifty closed and open-ended questions.

Undergraduate Economics students from the University of Johannesburg were recruited as the fieldworkers for the research project. The students were extensively trained in the technical aspects of the questionnaire by using role-play, amongst other things, to practise the interviewing techniques. The questionnaire was tested in a trial run in the envisaged study area, before the fieldwork commenced. Final adjustments were made to a few questions that proved to be possibly ambiguous.

The precise size of the research population was not known beforehand; hence it was not possible to use a classical random sampling framework and strategy. Non-probability sampling techniques in the form of a combination of availability and snowball sampling were therefore employed in the study to identify the respondents for this study.

The fieldworkers were accompanied by the authors and all the shopping centres adjacent to the main roads in the chosen research area (Roodepoort and Crown Mines) were visited as part of the study. Wherever possible, the shopping centre management was approached to get permission to interview the car guards on their premises. If permission was not granted, the fieldworkers moved on to the next shopping centre in the research area. The fieldwork was conducted in October and November 2017, and 110 interviews were conducted with the car guards in the research area. Less than one in ten of the potential respondents who were approached, chose not to participate. As part of the ethical conduct and principles of the study, they were under no obligation to provide any reasons. The response rate was therefore more than $90 \%$.

The questionnaires were checked and where mistakes and other issues (e.g. incomplete sections) were picked up, the questionnaire was excluded from the analysis. The fieldwork itself as well as the research project in its entirety adhered to all accepted and standard ethical norms and standards for this type of research. This research is an extension of the study on underemployment and unemployment in the South African informal sector. Ethical clearance was granted for this study by the Economic and Management Sciences Research Ethics committee of North-West University (ethics number: NWU00440-17-A4). Principles such as voluntary participation, informed consent and confidentiality were continuously adhered to during the fieldwork.

\section{Results}

After the data cleaning process, 104 questionnaires were considered feasible to include in the study. The countries of origin of the respondents are summarised in Table 1. The majority of the respondents were migrants or refugees, which corresponds to other studies where the majority were also found to be migrants (Steyn et al., 2015; Theodore et al., 2018). For the remainder of this study, the respondents from South Africa and England were not considered. The 
Table 1 Country of origin of respondents

\begin{tabular}{lrc}
\hline Country of origin & $\mathrm{n}$ & $\%$ \\
\hline Zimbabwe & 67 & 64 \\
Democratic Republic of the Congo & 17 & 16 \\
$\quad$ (DRC) & 12 & 12 \\
South Africa (SA) & 5 & 5 \\
Burundi & 1 & 1 \\
Mozambique & 1 & 1 \\
Lesotho & 1 & 1 \\
England & 104 & $100 \%$ \\
Total & &
\end{tabular}

sample size was therefore reduced to 91 to focus exclusively on migrant car guards.

The biographic and demographic characteristics of the sample will be briefly discussed first and thereafter the objective and subjective indicators of the lived experiences of migrant car guards.

Biographic and demographic characteristics

Table 2 provides a summary of the main biographic and demographic characteristics of migrant respondents. The majority of the respondents were male and in their economically active years. It can also be seen that the migrant car guards had numerous dependants to care for. Only $9 \%$ of the sample had no dependants, while $69 \%$ had three or more dependants.

The results show that the most significant proportion of the sample had had some secondary schooling or had completed secondary school $(41 \%$ and $31 \%$ respectively) and only $14 \%$ had had primary school education or less. In their Tshwane study, Steyn et al. (2015) also found that several migrant car guards had completed secondary schooling.

Objective indicators such as previous employment, job-seeking history and income received will be discussed in the next section.

Objective indicators

\section{Employment and employment-seeking history}

General results of the employment history of respondents are captured in Table 3. The respondents indicated that only $26 \%$ had previously been employed on a full-time basis with benefits. Most of the respondents that had full-time employment had previously worked as security guards or as artisans. Three migrants indicated that they had been teachers in their home countries (two were from Zimbabwe and one from Burundi). The remaining
Table 2 Biographic and demographic summary of migrant car guards in the sample

\begin{tabular}{|c|c|c|c|c|c|}
\hline & $\mathrm{n}$ & $\%$ & & $\mathrm{n}$ & $\%$ \\
\hline Gender & & & Dependants & & \\
\hline Male & 89 & 98 & None & 8 & 9 \\
\hline \multirow[t]{2}{*}{ Female } & 2 & 2 & $1-2$ & 20 & 22 \\
\hline & & & $3-4$ & 33 & 36 \\
\hline Age (years) & & & 5 or more & 30 & 33 \\
\hline$<20$ & 2 & 2 & & & \\
\hline $20-25$ & 18 & 20 & Education & & \\
\hline $26-30$ & 17 & 19 & None & 4 & 4 \\
\hline $31-35$ & 21 & 23 & Some primary schooling & 2 & 2 \\
\hline $36-40$ & 14 & 15 & Primary schooling completed & 7 & 8 \\
\hline $41-45$ & 7 & 8 & Some secondary schooling & 37 & 41 \\
\hline $46-50$ & 7 & 8 & Secondary schooling completed & 28 & 31 \\
\hline$>50$ & 5 & 5 & Post-school qualification & 13 & 14 \\
\hline Relationship status & & & Vocational training & & \\
\hline Single & 20 & 22 & None & 25 & 27 \\
\hline Divorced & 2 & 2 & Some training & 66 & 73 \\
\hline Married/Living together & 67 & 74 & & & \\
\hline Widow/Widower & 2 & 2 & & & \\
\hline
\end{tabular}


Table 3 Employment history and working as a car guard

\begin{tabular}{|c|c|c|c|c|c|}
\hline & $\mathrm{n}$ & $\%$ & & $\mathrm{n}$ & $\%$ \\
\hline Previous full-time employment & 24 & 26 & Duration as a car guard & & \\
\hline \multirow[t]{2}{*}{ Want a full-time job } & 81 & 89 & Less than a year & 17 & 19 \\
\hline & & & $1-2$ years & 13 & 14 \\
\hline Previous jobs & & & $2-5$ years & 31 & 34 \\
\hline Security guard & 8 & 33 & More than 5 years & 30 & 33 \\
\hline Artisan & 8 & 33 & & & \\
\hline Teacher & 3 & 13 & Unemployment duration & & \\
\hline Manager & 2 & 8 & Immediately employed as car guard & 19 & 21 \\
\hline Clerk & 1 & 4 & Less than a year & 22 & 24 \\
\hline Salesman & 1 & 4 & $1-2$ years & 24 & 26 \\
\hline Soccer player & 1 & 4 & More than 2 years & 26 & 29 \\
\hline
\end{tabular}

respondents, who had been full-time employees before becoming car guards, had been employed as clerks, a branch manager, a salon manager and a professional soccer player. The average time that these respondents had been employed in their last full-time job was 4.5 years. Two respondents had been employed for 15 and 17 years, respectively.

Although the respondents were employed as car guards when the survey was conducted, $89 \%$ specified that they would rather have full-time employment. This could indicate their unhappiness with the labour market and the socio-economic outcomes of their current occupation. It could also imply that they saw their work as a car guard as a temporary means to ensure material survival and not a substitute for full-time employment.

\section{Working as a car guard}

Table 3 shows that $21 \%$ of respondents immediately started working as car guards when they lost their previous employment. Most (29\%) were unemployed for more than two years before working as a car guard.

Furthermore, $33 \%$ of respondents indicated that they had been employed as car guards for more than 5 years. This trend could indicate the barriers to entry to the formal sector that migrants and refugees face (McEwen \& Leiman, 2008). It also corresponds with the long-term nature of other informal income-earning activities of foreign migrants in South Africa, such as day labouring (Theodore et al., 2017, 2018).

\section{Income and working conditions}

As was mentioned in the literature review on car guards, the net income that a car guard receives is dictated by the discretion of motorists and the daily tariff that has to be paid to an agency or the shopping centre where the guard works. The survey included three questions regarding the gross income that respondents received daily. These questions asked how much gross income a respondent received on average during a good day, a bad day and the day before the interview took place (termed as 'yesterday').

Figure 1 shows that $87 \%$ of the respondents earned more than R100 on a good day, but $88 \%$ earned less than R100 a day on a bad day. Regarding the day before the interview took place ('yesterday'), $47 \%$ of the respondents indicated that they had earned less than R100, whereas 53\% stated that they had made more than R100 for the day. The averages were R188 for a good day, R63 for a bad day and R111 for the day before the interview occurred. There is significant variability in the income that car guards received. This trend is similar to results from the study by Blaauw et al. (2013) which confirmed the uncertain levels of income in another informal market activity in which foreign migrants engaged, namely day labouring.

The survey also included questions on the number of days that respondents worked per week and the number of hours worked per day. The results show that respondents worked on average 5.5 days per week and $9 \mathrm{~h}$ a day. These results also correspond to the findings of Foster and Chasomeris (2017), namely 
Fig. 1 Gross daily income earned by migrant car guards

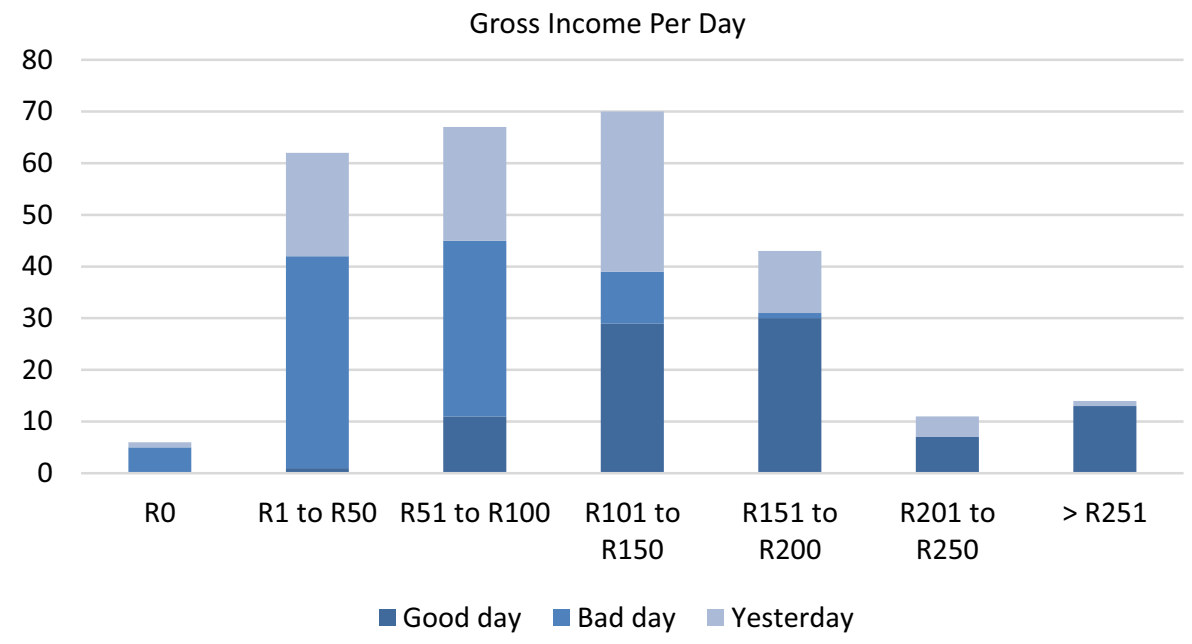

AVERAGE FEES PAID BY CAR GUARDS

that the average car guard in their Durban sample worked up to $9 \mathrm{~h}$ a day and 6 days a week.

The average hours worked and the average income earned per day were used to approximate how much respondents make per hour. It was estimated that respondents earned on average R20.04 per hour on a good day, and R6.71 and R12.33 per hour on a bad day and the day before the interview respectively. If these hourly rates are compared with the 2021 minimum wage of R21.69, the lived experience of migrant car guards is placed into perspective. To make matters worse, the daily fees that had to be paid to agencies or shopping centres had not been taken into account yet.

More than three-quarters (76\%) of the respondents indicated that they had to pay a fee to the shopping centre where they worked or to a car guard agency. The value of the daily fee payable ranged from either a standard fixed amount or a fee that corresponded to the size of the area (in terms of the number of parking bays) that they serviced. The bigger the site, the greater the fee. Figure 2 provides a summary of the fees paid by the respondents. The majority of respondents (42\%) paid a fee between R21 and R40 per day, while $7 \%$ indicated that they were responsible for paying a fee above R60 per day to serve their chosen area for the day. The average fee paid amounted to R28.33 per day. In addition to the daily fee that had to be paid, $37 \%$ of respondents also indicated that they had to pay for the work clothing that they were required to wear during working hours.

The subjective indicators of the lived experiences of migrant car guards will be discussed next.

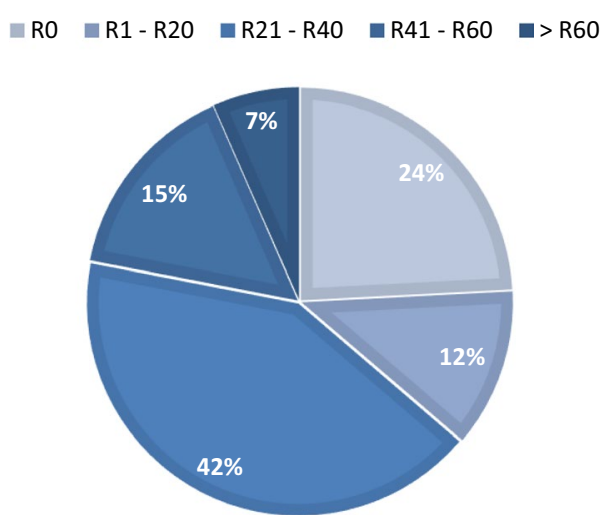

Fig. 2 Average fees paid by the respondents to shopping centres or agencies

\section{The subjective well-being of migrant car guards}

The questionnaire included a question to measure the SWB of migrant car guards at the time of the interview. The question was derived from the National Income Dynamics Study (NIDS) first wave, which measures the self-reported SWB of individuals (NIDS, 2008, p. 26). The question is a Likert scale measure which was phrased as: "On a scale of 1-10 (10 being very happy and 1 very unhappy), how happy are you with life at the moment?" According to Rojas (2013, p. 170), most studies that focus on informal employment gauge this sector only in objective indicators. There is 
an additional value that accompanies subjective measures, like SWB, where "it is the role of people themselves to judge the quality of their life, and their job" (Rojas, 2013, p. 170). As far as could be determined, there has not been any research to date that considers the SWB of migrant car guards in South Africa.

Figure 3 summarises the SWB levels of the sample of migrant car guards. Out of the 91 respondents, $40 \%$ indicated that they were "very dissatisfied" with their lives when the survey was conducted (the sum of 1 and 2 on the Likert scale). In contrast, only $10 \%$ indicated that they were "very satisfied" (the sum of 9 and 10 on the Likert scale). There was an apparent clustering of responses towards the lower bounds of SWB-just over 71\% of the sample chose an SWB level of five or lower. This tendency could allude to the underlying unhappiness of the respondents in the sample with their labour market and socio-economic outcomes of their migration effort.

Furthermore, this trend is not evident in other informal economic activities such as waste picking in South Africa. Waste picking is mostly done by South Africans. In a study investigating the SWB of waste pickers on selected landfill sites in the Free State, Blaauw et al. (2020) found evidence of surprisingly high levels of SWB using the same NIDS measure as this study. Some of the factors responsible for the surprising finding may include the notion of being in control of the income they earn-to a degree at least. Waste pickers know precisely what

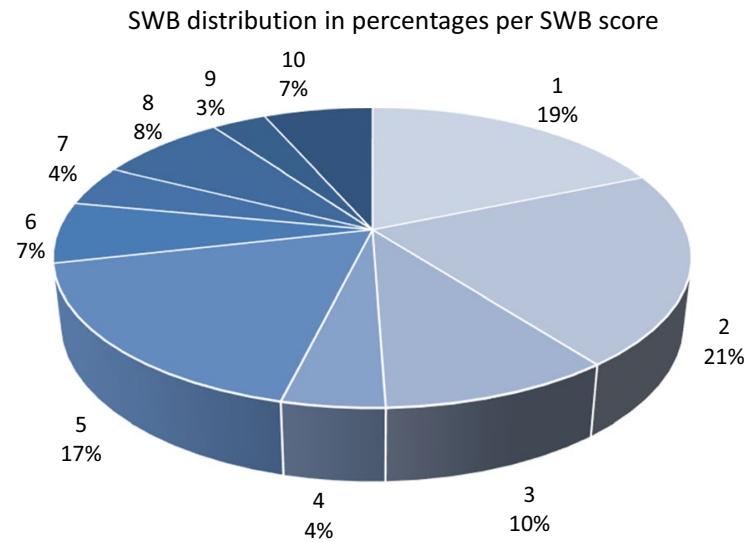

Fig. 3 Distribution of the subjective well-being of migrant car guards the various recyclables' prices are that they will make through their collecting endeavours. The more they can collect, the higher the income (Blaauw et al., 2020).

Car guards, on the other hand, have no control over their income. They are at the mercy of motorists' willingness to donate and have no endogenous control over this process. Their best efforts at being friendly and providing a service to motorists may be in vain. This uncertainty weighs heavily on the subconscious of the car guards - as expressed by them during the formal interviews.

It is customary in the SWB literature to estimate SWB regression functions to identify possible significant determinants of SWB of the respondents in question. Investigating these determinants, in this case, could help us identify the typical social and economic vulnerabilities that migrant car guards experience daily. Distinct determinants found in the literature on SWB in informal economy settings include demographic variables (which mainly act as control variables in the regression), economic variables, and other variables that could typically influence the SWB of a respondent (Blaauw et al., 2013, 2020; Rojas, 2013). The possible determinants that were included in the car guards' SWB function are listed in Table 4.

The SWB function was estimated by using an ordered probit model, which accommodates the ordinal nature of the dependent variable (SWB). The results for the model are presented in Table 5.

The results from the ordered probit model show that many of the variables usually included in SWB models were insignificant. The insignificance of all the demographic variables shows that none of these factors significantly influenced a respondent's SWB. Both economic variables had a significant effect on SWB. A respondent's income had a positive relationship with SWB (in this case, tips received on a bad day represented income, tips received on a good day were also tested but found to be insignificant). This finding corresponds with research by both Diener et al. (2009) and Cummins (2000), who confirmed that income influences the SWB of poor people. However, this finding is in contrast with recent studies on the SWB of waste pickers in South Africa (Blaauw et al., 2020).

The importance of income for the SWB for foreign migrants working as car guards is possibly grounded in the commitment these men have to provide for 
Table 4 Description of variables included in SWB regression

\begin{tabular}{|c|c|c|}
\hline Variable & Variable name & Description \\
\hline \multicolumn{3}{|l|}{ Demographic variables } \\
\hline Gender (Female omitted) & Male & $\begin{array}{l}\text { Dummy variable }(D=1 \text { if the respondent is male; } \\
D=0 \text { otherwise) }\end{array}$ \\
\hline Age & Age and age squared & Age in years \\
\hline \multirow[t]{3}{*}{$\begin{array}{l}\text { Education (Post-school qualifications have been } \\
\text { omitted) }\end{array}$} & No schooling & $\begin{array}{l}\text { Dummy variable }(D=1 \text { if the respondent had no } \\
\text { schooling; } D=0 \text { otherwise })\end{array}$ \\
\hline & Completed primary schooling & $\begin{array}{l}\text { Dummy variable }(D=1 \text { if the respondent com- } \\
\text { pleted primary schooling; } D=0 \text { otherwise) }\end{array}$ \\
\hline & Completed secondary schooling & $\begin{array}{l}\text { Dummy variable }(D=1 \text { if the respondent com- } \\
\text { pleted secondary schooling; } D=0 \text { otherwise })\end{array}$ \\
\hline \multirow[t]{2}{*}{$\begin{array}{l}\text { Home language (Other languages have been } \\
\text { omitted) }\end{array}$} & Shona & $\begin{array}{l}\text { Dummy variable ( } D=1 \text { if the respondent's home } \\
\text { language is Shona; } D=0 \text { otherwise) }\end{array}$ \\
\hline & French & $\begin{array}{l}\text { Dummy variable }(D=1 \text { if the respondent's home } \\
\text { language is French; } D=0 \text { otherwise) }\end{array}$ \\
\hline \multirow[t]{3}{*}{$\begin{array}{l}\text { Marital status (Other statuses have been omit- } \\
\text { ted) }\end{array}$} & Married & $\begin{array}{l}\text { Dummy variable }(D=1 \text { if the respondent is mar- } \\
\text { ried, } D=0 \text { otherwise) }\end{array}$ \\
\hline & Divorced & $\begin{array}{l}\text { Dummy variable }(D=1 \text { if the respondent is mar- } \\
\text { ried; } D=0 \text { otherwise })\end{array}$ \\
\hline & Living with a partner & $\begin{array}{l}\text { Dummy variable }(D=1 \text { if the respondent is mar- } \\
\text { ried; } D=0 \text { otherwise) }\end{array}$ \\
\hline Dependants & Dependants & Number of dependants \\
\hline \multicolumn{3}{|l|}{ Economic variables } \\
\hline \multirow[t]{2}{*}{ Income } & Tip on a bad day & $\begin{array}{l}\text { Income in South African Rands received on a } \\
\text { bad day }\end{array}$ \\
\hline & Tip on a good day & $\begin{array}{l}\text { Income in South African Rands received on a } \\
\text { good day }\end{array}$ \\
\hline Looking for a full-time job & full-time job & $\begin{array}{l}\text { Dummy variable ( } D=1 \text { if the respondent would } \\
\text { like a full-time job; } D=0 \text { otherwise) }\end{array}$ \\
\hline \multicolumn{3}{|l|}{ Car guard-specific variables } \\
\hline Years as a car guard & Duration & Number of years working as a car guard \\
\hline Experienced crime & Experienced crime & $\begin{array}{l}\text { Dummy variable }(\mathrm{D}=1 \text { if the respondent has } \\
\text { experienced crime while on duty; } \mathrm{D}=0 \text { other- } \\
\text { wise) }\end{array}$ \\
\hline Pay to work & Pay to work & $\begin{array}{l}\text { Dummy variable ( } \mathrm{D}=1 \text { if the respondent has to } \\
\text { pay to work; } 0 \text { otherwise) }\end{array}$ \\
\hline Pay for clothes & Pay for clothes & $\begin{array}{l}\text { Dummy variable ( } D=1 \text { if the respondent has to } \\
\text { pay for the clothes worn while on duty; } D=0 \\
\text { otherwise) }\end{array}$ \\
\hline Working days per week & Days per week & Number of days that a car guard works per week \\
\hline Training received & Training & $\begin{array}{l}\text { Dummy variable }(D=1 \text { if the respondent } \\
\text { received any form of training before starting to } \\
\text { work as a car guard; } D=0 \text { otherwise })\end{array}$ \\
\hline \multicolumn{3}{|l|}{ Other variables } \\
\hline Lagged SWB & SWB $(-1)$ & Value of SWB in the previous period \\
\hline \multirow[t]{2}{*}{$\begin{array}{l}\text { Weather conditions (other conditions have been } \\
\text { omitted) }\end{array}$} & Rain & $\begin{array}{l}\text { Dummy variable }(\mathrm{D}=1 \text { if it was a rainy day } \\
\text { when the interview was conducted; } \mathrm{D}=0 \\
\text { otherwise) }\end{array}$ \\
\hline & Hot & $\begin{array}{l}\text { Dummy variable }(D=1 \text { if the temperature was } \\
\text { over } 30 \text { degrees Celsius when the interview } \\
\text { was conducted; } D=0 \text { if otherwise) }\end{array}$ \\
\hline
\end{tabular}


Table 5 Results of the ordered probit model with subjective well-being as the dependent variable

\begin{tabular}{|c|c|c|}
\hline & Coefficient & p-value \\
\hline \multicolumn{3}{|l|}{ Demographic variables } \\
\hline Male & -0.8926 & 0.3586 \\
\hline Age & 0.0261 & 0.7272 \\
\hline Age squared & -0.0002 & 0.8485 \\
\hline Shona & 0.2548 & 0.5016 \\
\hline French & 0.4511 & 0.3297 \\
\hline Married and living with a partner & -0.0725 & 0.8242 \\
\hline Divorced & -0.7998 & 0.4475 \\
\hline Dependants & 0.0127 & 0.8246 \\
\hline No schooling & -0.4639 & 0.4188 \\
\hline Completed primary schooling & 0.4105 & 0.4300 \\
\hline Completed secondary schooling & 0.0210 & 0.9447 \\
\hline \multicolumn{3}{|l|}{ Economic variables } \\
\hline Tip on a bad day & $0.0079 * *$ & 0.0204 \\
\hline Full-time job & $-0.6612 * *$ & 0.0212 \\
\hline \multicolumn{3}{|l|}{ Car guard-specific variables } \\
\hline Duration & -0.0021 & 0.4552 \\
\hline Experienced crime & -0.0883 & 0.7332 \\
\hline Pay to work & -0.2047 & 0.4795 \\
\hline Pay for clothes & -0.3960 & 0.1685 \\
\hline Days per week & 0.1993 & 0.2669 \\
\hline Training & -0.2198 & 0.4790 \\
\hline \multicolumn{3}{|l|}{ Other variables } \\
\hline $\operatorname{SWB}(-1)$ & $0.1142 * *$ & 0.0139 \\
\hline Rain & $-0.8022 *$ & 0.0768 \\
\hline Hot & -0.3891 & 0.2426 \\
\hline Pseudo R-squared & 0.078281 & \\
\hline
\end{tabular}

* Significant at $10 \%$; * significant at $5 \%$; ** significant at $1 \%$

families back home. The fact that they migrated implies the physical separation of family members (Simoni \& Voirol, 2021). The separation can generate moral breakdowns. They constantly have to face questions about how to 'properly' fulfil one's role and obligations towards relatives left behind (Simoni \& Voirol, 2021). Income earned in South Africa determines the value of remittances sent home and the possibility of revisiting their families. The concern of not being able to send money home weighs heavily on the minds of car guards. This was a constant theme in discussions with the respondents during the fieldwork and is an important area for further qualitative research.
There is a clearly negative relationship between a respondent's SWB and their desire to have a full-time job. This negative relationship could underpin the respondent's unhappiness with their current job as a car guard. It reinforces the result of the income variable and the reasoning behind it as described above. None of the other car guard-specific factors turned out to be statistically significant-again reinforcing the importance of income in the lived reality and SWB of these foreign migrants.

The lagged value of the SWB variable was also find to be significant. According to Bottan and Truglia (2011), SWB could be autoregressive for individual-level data. The autoregressive relationship means that current SWB may depend on past levels of SWB. This seems to be the case for migrant car guards working in South Africa. The significance of the lagged variable underpins the view that "happiness is inertial: i.e., ceteris paribus, having greater feelings of happiness in the past directly increases the probability of feeling happy in the present" (Bottan $\&$ Truglia, 2011, p. 232). In the case of the migrant car guards in our study, this particular result points towards the long-term nature of the informal sector in South Africa and the fact the pressure to send remittances to their families back home is a constant theme in their levels of SWB.

Lastly, it was clear that the weather also had an impact on the SWB of the respondents. The model shows that rainy days had a negative influence on the SWB of migrant car guards. As mentioned previously, car guards work an average of nine hours a day, and one can imagine how long these working hours can feel if the work is done in the rain. Apart from the rainy weather and the inconvenience it brings, rain often means that fewer motorists frequent the particular shopping centre, resulting in lower income levels earned for that day.

\section{Conclusion}

Johannesburg remains an important city and context of reception for migrants from the rest of the African continent. Informal and a-typical forms of employment are often the only alternatives available to many migrants who are desperate to earn a living and send remittances to families in their home countries. 
The lived experiences of migrant car guards formed the focus of this study on an informal income-earning activity that is unique to South Africa in many respects.

The study revealed the extent and depth of the vulnerabilities experienced by migrant car guards, namely uncertain and low earnings levels, and standing in the harsh South Africa climate for nine hours a day, six days a week. The negative implications, both short- and long-term, for their lives and livelihoods are apparent. Their vulnerabilities go further. Along with other migrant workers in South Africa, car guards often experience different levels of xenophobia (e.g., physical and verbal abuse and violence at the hands of the community), lack of legal documentation and very little legal recourse to counter any of these challenges (Crush et al., 2015a, 2015b). For migrant car guards, a combination of such factors may result in limited choices in terms of employment. They often have no other option but to tolerate sub-standard employment in the informal sector as there are no other viable opportunities available to them (Theodore et al., 2017). The two realities of their daily lives (i.e., being a car guard and a migrant) imply that they just manage to survive and are often exploited (Also see Foster \& Chasomeris, 2017). They have little or no scope to get jobs in the formal sector, and as a result, the constant pressure to provide for dependants back home is always there. Being unable to meet this obligation leaves them in a permanent state of angst. Smit and Rugunanan (2014) confirm that these fears and daily struggles produce heightened feelings of emotional distress and a low sense of emotional well-being. The low level of wellbeing is also evident in the SWB analysis performed in this study.

The implications for further research from the lived experiences of migrant car guards are evident and vital. Bakewell (2010) noted that structural factors in migration theory are often understood only in terms of individuals. As far as migrant car guards are concerned, their relationship with car guard companies and shopping centres is a critical structural element of which the characteristics and legal position are unclear. Car guards' unique labour market status and relationship with the shopping centres and car guard companies deserve urgent research attention. Only when these are definitively established can policies to protect their human rights and dignity be developed and-more importantly-implemented. The alternative is a continuation of a situation where people hoping to provide a better future for their dependants will be that they are "30 and ... have nothing".

Acknowledgements We warmly thank the car guards for their willing participation in the research.

Authors' contributions All authors contributed to the study conception and design. Material preparation, data collection and analysis were performed by both authors. The first draft of the manuscript was written by both authors and all authors commented on previous versions of the manuscript. Both authors read and approved the final manuscript.

Funding We gratefully acknowledge the funding received from the School of Economics at the University of Johannesburg for the funding of the fieldwork.

Availability of data and material The raw data is available on reasonable request from the corresponding author.

\section{Declarations}

Conflicts of interest The authors declare that they have no conflict of interest.

Ethical approval The fieldwork and the research project adhered to all accepted and standard ethical norms and standards for this type of research. This research is an extension of the study on underemployment and unemployment in the South African informal sector. Ethical clearance was granted for this study by the Economic and Management Sciences Research Ethics committee of North-West University (ethics number: NWU-00440-17-A4).

Consent to participate Principles such as voluntary participation, informed consent and confidentiality were continuously adhered to during the fieldwork.

\section{References}

Asad, A. L. (2015). Contexts of reception, post-disaster migration, and socioeconomic mobility. Population and Environment, 36(3), 279-310. https://doi.org/10.1007/ s11111-014-0221-4

Bakewell, O. (2010). Some reflections on structure and agency in migration theory. Journal of Ethnic and Migration Studies, 36(10), 1689-1708. https://doi.org/10.1080/ 1369183X.2010.489382

Bernhardt, A., Spiller, M., \& Theodore, N. (2013). Employers gone rogue: Explaining industry variation in violations of labor standards. Industrial and Labor Relations Review, 66(4), 808-832. 
Bernstein, J. (2003). Car watch: Clocking informal parking attendants in Cape Town. Centre for Social Science Research, Social Surveys Unit.

Blaauw, P. F., \& Bothma, L. J. (2003). Informal labour markets as a solution for unemployment in South Africa: A case study of car guards in Bloemfontein. South African Journal of Human Resource Management, 1(2), 40-44.

Blaauw, P. F., Botha, I., Schenck, R., \& Schoeman, C. (2013). Happy in the informal economy? A case study of wellbeing among day labourers in South Africa. International Business \& Economics Research Journal, 12(6), 635-653.

Blaauw, P. F., Pretorius, A. M., Schoeman, C. H., \& Schenck, C. J. (2012). Explaining migrant wages: The case of Zimbabwean day labourers in South Africa. International Business \& Economics Research Journal, 11(1), 1333-1346.

Blaauw, P. F., Pretorius, A. M., Viljoen, K., \& Schenck, C. J. (2020). Adaptive expectations and subjective well-being of landfill waste pickers in South Africa's Free State province. Urban Forum, 31(1), 135-155. https://doi.org/10. 1007/s12132-019-09381-5

Bottan, N. L., \& Truglia, R. P. (2011). Deconstructing the hedonic treadmill: Is happiness autoregressive. The Journal of Socio-Economics, 40(3), 224-236.

Chambers, D. (2018). Car guard's R19,000 stash 'was more about tripping than tipping'. Retrieved November 12, 2021, from https://www.timeslive.co.za/news/southafrica/2018-09-27-car-guards-r19000-stash-was-moreabout-tripping-than-tipping/

Charman, A., \& Piper, L. (2012). Xenophobia, criminality and violent entrepreneurship: Violence against Somali Shopkeepers in Delft South, Cape Town, South Africa. South African Review of Sociology, 43(3), 81-105.

Charman, A., \& Petersen, L. (2015). A transnational space of business: The informal economy of Ivory Park, Johannesburg. In J. Crush, A. Chikanda, \& C. Skinner (Eds.), Mean streets: Migration, xenophobia and informality in South Africa (pp. 78-99). Cape Town: Southern African Migration Programme.

Corruptionwatch. (2016). Brave, honest car guard is our hero. Retrieved November 12, 2021, from https://www.corru ptionwatch.org.za/brave-honest-car-guard-hero/

Crea, T. M., Loughry, M., O’Halloran, C., \& Flannery, G. F. (2017). Environmental risk: Urban refugees' struggles to build livelihoods in South Africa. International Social Work, 60(3), 667-682.

Crush, J., Chikanda, A., \& Skinner, C. (2015a). Mean streets: Migration, xenophobia and informality in South Africa. Southern African Migration Programme.

Crush, J., \& Pendleton, W. (2007). Mapping hostilities: The geography of xenophobia in Southern Africa. South African Geographical Journal, 89, 64-82.

Crush, J., Skinner, C., \& Chikanda, A. (2015b). Informal migrant entrepreneurship and inclusive growth in South Africa, Zimbabwe, and Mozambique Migration Policy Series no. 68. Southern African Migration Programme.

Cummins, R. A. (2000). Personal income and subjective wellbeing: A review. Journal of Happiness Studies, 1(2), 133-158.

Danso, R. \& McDonald, D. (2000). Writing xenophobia: Immigration and the press in post-apartheid South Africa.
SAMP Migration Policy Series No. 17. Kingston and Cape Town: SAMP.

Diener, E., Lucas, R. E., Schimmack, U., \& Helliwell, J. F. (2009). Well-being for public policy. Oxford University Press.

Doussard, M. (2013). Degraded work: The struggle at the bottom of the labor market. University of Minnesota Press.

Foster, J., \& Chasomeris, M. (2017). Examining car guarding as a livelihood in the informal sector. Local Economy, 32(6), 525-538.

Foster, J., Chasomeris, M., \& Blaauw, D. (2021). Re-visiting car guarding as a livelihood in the informal sector. Development Southern Africa. https://doi.org/10.1080/03768 35X.2021.1891862

International Labour Organisation (ILO). (2004). Towards a fair deal for migrant workers in the global economy. Retrieved November 12, 2021, from https://www.ilo.org/ public/english/standards/relm/ilc/ilc92/pdf/rep-vi.pdf

International Organisation for Migration (IOM). (2019). Migration data portal. Retrieved April 7, 2020, from https://migrationdataportal.org/?i=stock_abs_\&t=2019\& $\mathrm{cm} 49=710$

Kitching, K. (1999). Die ekonomie van die motorwagbedryf: Bloemfontein as gevallestudie. Unpublished honours dissertation, University of the Free State, Bloemfontein.

Martinez, R., Buntin, T. J. \& Escalante, W. (2011). The policy dimensions of the context of reception for immigrants (and latinos) in the midwest. Retrieved November 12, 2021, from www.cambio.missouri.edu/Library/

McEwen, H. \& Leiman, A. (2008). The car guards of Cape Town: A public good analysis. University of Cape Town (Southern Africa Labour and Development Research Unit).

McKnight, J. (2008). Through the fear: A study of xenophobia in South Africa's refugee system. Journal of Identity and Migration Studies, 2(2), 18-42.

Morapedi, W. (2007). Post-liberation xenophobia in southern Africa: The case of the influx of undocumented Zimbabwean immigrants into Botswana, c. 1995-2004. Journal of Contemporary African Studies, 25(2), 229-250.

Myroniuk, T. W., \& Vearey, J. (2014). Social capital and livelihoods in Johannesburg: differential advantages and unexpected outcomes among foreign-born migrants, internal migrants, and long-term South African residents. International Migration Review, 48(1), 243-273.

NIDS (National Income Dynamics Study). (2008). Adult questionnaire, national income dynamics survey. SALDRU, UCT School of Economics, Cape Town.

Nkomo, T. S. (2019). Exploring Congolese refugees and asylum seekers' survival strategies in South Africa: Implication for social work practice. Journal of Human Behavior in the Social Environment, 29(4), 499-518.

Portes, A., \& Bach, R. L. (1985). Latin journey: Cuban and Mexican immigrants in the United States. University of California Press.

Portes, A., \& Rumbaut, R. (2006). Immigrant America: A Portrait. University of California Press.

Potgieter, P. J., Michell, L. J., Munnik, E. E., \& Ras, J. M. (2003). Bivariate analysis of car guard activities as a 
crime prevention initiative. Acta Criminologica, 16(3), 35-49.

Rojas, M. (2013). The subjective well-being of people in informal employment: Empirical evidence from Mexico. Evidence-Based HRM: A Global Forum for Empirical Scholarship, 1(2), 169-186.

Saunders, S. G., \& Lynn, M. (2010). Why tip? An empirical test of motivations for tipping car guards. Journal of Economic Psychology, 31, 106-113.

Saunders, S. G. \& Petzer, D. J. (2009). Consumer tipping: a study of the car guarding industry. Retrieved July 26, 2019, from http://hdl.handle.net/10210/5316

Simoni, V., \& Voirol, J. (2021). Remittances and morality: Family obligations, development, and the ethical demands of migration. Journal of Ethnic and Migration Studies, 47(11), 2516-2536. https://doi.org/10.1080/1369183X. 2020.1779678

Smit, R., \& Rugunanan, P. (2014). From precarious lives to precarious work: The dilemma facing refugees in Gauteng, South Africa. South African Review of Sociology, 45(2), 4-26.

Solé, C., Ribas, N., Bergalli, V., \& Parella, S. (1998). Irregular employment amongst migrants in Spanish cities. Journal of Ethnic and Migration Studies, 24(2), 333-346. https:// doi.org/10.1080/1369183X.1998.9976636

South African Police Service. (SAPS). (2018). SAPS Crime Stats 2017/18. South African Police Service.

Statistics South Africa. (2018). Migrants flock to Gauteng. Retrieved April 7, 2020, from http://www.statssa.gov. $\mathrm{za} / \mathrm{p}=11331$

Statistics South Africa. (2020). P0341-Victims of Crime Survey, 2019. Retrieved November 12, 2021, from http:// www.statssa.gov.za/? $\mathrm{p}=13811$

Steyn, F. (2018). Om na uitbuiting toe te vlug: Die geval van immigrante wat as motorwagte werk. Tydskrif Vir Geesteswetenskappe, 58(4-2), 925-939.

Steyn, F., Coetzee, A., \& Klopper, H. (2015). A survey of car guards in Tshwane: Implications for private security policy and practice. SA Crime Quarterly, 52, 15-24.

Tawodzera, G., Chikanda, A., Crush, J. \& Tengeh, R. (2015). International migrants and refugees in Cape Town's informal economy, Migration Policy Series no. 70. Southern African Migration Programme
Tevera, D. S. (2013). African migrants, xenophobia and urban violence in post-apartheid South Africa. Alternation, Special Issue Number, 7, 9-26.

Theodore, N., Blaauw, P. F., Pretorius, A. M., \& Schenck, C. J. (2017). The socio-economic incorporation of migrant and native-born day labourers in Tshwane, South Africa. International Migration, 55(1), 142-156.

Theodore, N., Meléndez, E., \& Valenzuela, A., Jr. (2009). Worker centers: Defending labor standards for migrant workers in the informal economy. International Journal of Manpower, 30(5), 422-436.

Theodore, N., Pretorius, A. M., Blaauw, P. F., \& Schenck, C. (2018). Informality and the context of reception in South Africa's new immigrant destinations. Population, Space and Place, 24, e2119. https://doi.org/10.1002/psp.2119

Thompson, D. K. (2016). Risky business and geographies of refugee capitalism in the Somali migrant economy of Gauteng, South Africa. Journal of Ethnic and Migration Studies, 42(1), 120-135. https://doi.org/10.1080/13691 83X.2015.1073580

Viljoen, J. M. M., Blaauw, P. F., \& Schenck, R. (2018). "Sometimes you don't make enough to buy food": An analysis of South African street waste pickers' income. Journal of Economic and Financial Sciences, 11(1), a186. https:// doi.org/10.4102/jef.v11i1.186

Visser, M. A. (2017). Reshaping migrant labour market geographies: Local regularisations and the informal economy. Population, Space and Place, 23(7), e2025. https://doi. org/10.1002/psp.2025

Winders, J. (2014). New immigrant destinations in global context. International Migration Review, 49(s1), s149-s179.

Woolfson, C., Fudge, J., \& Thörnqvist, C. (2014). Migrant precarity and future challenges to labour standards in Sweden. Economic and Industrial Democracy, 35(4), 695-715.

Publisher's Note Springer Nature remains neutral with regard to jurisdictional claims in published maps and institutional affiliations. 